\title{
FAKTOR-FAKTOR YANG BERHUBUNGAN DENGAN PERILAKU WANITA USIA DALAM MELAKUKAN DETEKSI DINI KANKER SERVIKS DI DESA JATIMULYA WILAYAH KERJA PUSKESMAS PEDES KABUPATEN KARAWANG
}

\author{
CONNECTED FACTORS WITH BEHAVIOR AGE WOMEN IN DOING EARLY DETECTION \\ OF CERVIC CANCER IN JATIMULYA PRIMARY HEALT CARE PEDES IN KARAWANG
}

\author{
Mardianti ${ }^{1}$, Debi Citra ${ }^{2}$ \\ 1,2 Prodi Kebidanan Karawang, Poltekkes Kemenkes Bandung \\ Email: farahfahri@gmail.com
}

\begin{abstract}
ABSTRAK
Jawa Barat menempati peringkat ke-5 dengan jumlah kasus kanker leher rahim sebanyak 5.786 orang atau sekitar 11,78\%. Berdasarkan data DKK kabupaten Karawang deteksi dini kanker serviks dengan pemeriksaan IVA sebanyak 10,2\% (2012), 29,6\% (2013). Data di puskesmas Pedes pemeriksaan IVA sebanyak 17,8\% orang pada tahun 2012, 19,7\% orang pada tahun 2013 menunjukan bahwa terjadi peningkatan deteksi dini kanker serviks. Namun masih belum mencapai target yaitu $80 \%$. Tujuan penelitian adalah diketahuinya faktor-faktor yang berhubungan dengan perilaku wanita usia subur dalam melakukan deteksi dini kanker serviks di desa jatimulya wilayah kerja Puskesmas Pedes Kabupaten Karawang tahun 2013. Penelitian ini menggunakan metode analitik dengan rancangan Cross Sectional. Sampel penelitian ini adalah wanita usia subur yang telah menikah. Pengambilan sampel dengan teknik multistage random


melakukan deteksi, 98 responden (75,4\%) tidak melakukan deteksi. Berdasarkan uji statistik menunjukan 6 variabel yang diteliti di dapatkan 4 variabel yang bermakna yaitu variabel pendidikan $p=0,046(p \leq 0,05)$, variabel pengetahuan $p=0,008$ ( $p \leq 0,05)$, variabel sosial ekonomi $p=0,000(p \leq 0,05)$ dan dukungan keluarga $p=0,037(p \leq 0,05)$ sedangkan variabel yang tidak bermakna adalah umur dan jarak ketempat pelayanan kesehatan. Disarankan pada puskesmas meningkatkan sosialisasi mengenai, faktor resiko dan deteksi dini kanker serviks.
\end{abstract}

Kata Kunci: Wanita Usia Subur, Kanker Serviks

\section{ABSTRACT}

West Java ranked 5th with the number of cervical cancer cases as many as 5,786 people or around 11.78\% . Based on data from the Karawang district health office early detection of cervical cancer with IVA examination as much as 10.2\% in 2012, 29.6\% in 2013. Medical record at Puskesmas Pedes IVA examination as much as 17.8\% (2012), 19.7\% of people (2013). These data show that there has been an increase in Cervical Cancer Early Detection. But it still has not reached the target of an early cervical cancer detection program which is $80 \%$. The purpose of this study is to know the factors related to the behavior of women of childbearing age in early detection of cervical cancer in the village in the early working area of Pedes Public Health Center, Karawang District in 2013. This study used analytical methods with Cross Sectional design. The sample of this study were married women of childbearing age. Sampling with multistage random sampling technique, on 130 respondents using the level of significance $(p \leq 0.05)$. The results of the study found that as many as 32 respondents (24.6\%) had done early detection of cervical cancer while 98 respondents (75.4\%) did not do early detection of cervical cancer. Based on the results of statistical tests showed that the 6 variables studied obtained 4 variables meaningful and 2 meaningless variables. The meaningful variables are education variables $p=0.046(p \leq 0.05)$, knowledge variables $p=0.008(p \leq 0.05)$, socioeconomic variables $p=0.000$ $(p \leq 0.05)$ and family support $p=0.037$ ( $p \leq 0.05)$ while the non-meaningful variables are age and distance to the place of health services. It is recommended that the puskesmas improve socialization regarding, risk factors and early detection of cervical cancer.

Keywords: women of childbearing age, cervical cancer 


\section{PENDAHULUAN}

Perempuan yang aktif secara seksual memiliki resiko terinfeksi kanker serviks atau tahap awal penyakit ini tanpa memandang usia atau gaya hidup.Kesehatan Reproduksi menurut WHO adalah suatu keadaan fisik mental dan soaial yang utuh bukan hanya bebas dari penyakit atau kecacatan dalam segala aspek yang berhubungan dengan system reproduksi, fungsi serta prosesnya. Kesehatan reproduksi merupakan hal yang sangat penting bagi setiap orang dan tak memandang gender kesehatan reproduksi identik dengan kehidupan dengan seorang wanita terutama, khususnya remaja. Banyak sekali beberapa permasalahan yang menyangkut dari kesehatan reproduksi ini, salah satunya adalah $\mathrm{Ca}$ Cervix yang merupakan pembunuh wanita pertama di dunia (Bertiani, 2009).

Setiap tahun, ratusan ribu kasus HPV terdiagnosa di dunia dan ribuan wanita meninggal karena kanker serviks. Kanker serviks atau kanker leher Rahim adalah jenis penyakit kanker yang terjadi pada daerah leher Rahim, yaitu bagian Rahim yang terletak di bawah, yang membuka kearah liang vagina. Berawal dari leher Rahim, apabila telah memasuki tahap lanjut, kanker ini bias menyebar ke organ-organ lain di seluruh tubuh (Bertiani 2009). WHO menyatakan, saat ini penyakit kanker serviks menempati peringkat teratas di antara berbagai jenis kanker yang menyebabkan kematian pada perempuan di dunia. Prevalensi kasus Ca Cerviks (kanker serviks) di dunia mencapai 1,4 juta dengan 493.000 kasus baru dan 273.000 kematian. Dari data tersebut lebih dari $80 \%$ penderita berasal lebih banyak. Kemampuan tersebut telah di buktikan oleh berbagai penelitian (Rasjidi, 2012)

Saat ini kanker merupakan salah satu penyebab kematian terbanyak di dunia. World Health Organitation (WHO) menyatakan, pada tahun 2015, diperkirakan ada 9 juta orang yang meninggal karena kanker dan tahun 2030 diperkirakan ada 11,4 juta kematian karena kanker. Menurut data Departemen Kesehatan (Depkes), kanker merupakan penyebab kematian ke-5 di Indonesia dan mengalami peningkatan secara bermakna. Ironisnya, di negara berkembang, 8090 persen biasanya tidak dapat disembuhkan karena penderita datang dalam stadium yang telah lanjut.

Kanker serviks mempunyai frekuensi relatif tertinggi $(25,6 \%) \mathrm{di}$ Indonesia. Di Indonesia, insidensi kejadian kanker leher rahim paling tinggi dibandingkan jenis kanker lainnya. Setiap tahunnya terjadi 180.000 sampai 200.000 kasus baru kanker leher rahim, kata Dr. Adi Budi Harsono, Sp.OG., dari RSHS Bandung pada seminar "Penanggulangan Kanker Alat Reproduksi Perempuan", yang digelar Yayasan Kanker Indonesia Cabang Jabar dan BKKBN Jabar dari rumah sakit (SIRS) tahun 2008, prevalensi nasional penyakit kanker leher Rahim tertinggi adalah di D.I Yogyakarta $(15,96 \%)$ dan terendah di Maluku $(1,15 \%)$. Sedangkan jawa barat menempati peringkat ke-5 dengan jumlah kasus kanker leher Rahim sebanyak 5.786 orang atau sekitar $11 ; 78 \%$. Angka kejadian ini meningkat di bandingkan dengan tahun sebelumnya yaitu sekitar 10,38\% (SIRS, 2009)

Berdasarkan data dinas kesehatan kabupaten karawang deteksi dini kanker serviks dengan pemeriksaan IVA sebanyak $10,2 \%$ pada tahun 2012, $29,6 \%$ pada tahun 2013 dan angka kejadian kanker serviks di puskesmas pedes 11 orang pada tahun 2013 (profil IVA dinkes kabupaten karawang 2013), sedangkan data rekam medik di puskesmas Pedes deteksi dini kanker serviks dengan pemeriksaan IVA 
sebanyak $17,8 \%$ pada tahun 2012, $19,7 \%$ pada tahun 2013. Data tersebut menunjukan bahwa telah terjadi penigkatan Deteksi Dini Kanker Serviks. Namun masih belum mencapai target dari program deteksi dini kanker serviks yaitu $80 \%$ (profil IVA puskesmas pedes 2013)

Sedangkan berdasarkan data rekam medik di desa jatimulya wilayah kerja puskesmas pedes deteksi dini kanker serviks dengan pemeriksaan IVA adalah $0,8 \%$ Ini merupakan desa dengan cakupan IVA terendah dibandingkan desa lainnya yang ada diwilayah kerja puskesmas pedes tahun 2013. Berdasarkan data tersebut menunjukan bahwa masih rendahnya deteksi dini kanker serviks (profil IVA puskesmas pedes 2013)

\section{METODE PENELITIAN}

Penelitian ini adalah penelitian survey analitik dengan pendekatan cross sectional. Penelitian dilaksanakan di desa jatimulya wilayah kerja puskesmas pedes Kabupaten Karawang. Penelitian dilaksanakan pada bulan januari sampai dengan juni 2014. Populasi adalah keseluruhan objek penelitian yang akan diteliti. Berdasarkan pengertian tersebut yang menjadi populasi dalam penelitian ini adalah semua wanita usia subur yang telah menikah di desa jatimulya wilayah kerja puskesmas pedes berjumlah 2030 orang. Teknik pengambilan sampel dengan cara Multistage Random Sampling. Teknik selanjutnya adalah propotional sampel. Teknik pengambilan sampel proporsi atau sampel imbangan ini dilakukan untuk menyempurnakan penggunaan teknik multistage random sampling. Jumlah populasi per RT dibagi jumlah total populasi satu desa dikali jumlah sampel desa. Teknik sampling yang selanjutnya adalah pengambilan sampel, secara acak sederhana atau simple random sampling, jumlah sampel 130 orang.

\section{HASIL PENELITIAN DAN PEMBAHASAN}

Tabel 1 Distribusi Frekuensi Perilaku WUS

Melakukan Deteksi Dini Kanker Serviks di Desa Jatimulya wilayah Kerja Puskesmas Pedes

\begin{tabular}{ccc}
\hline $\begin{array}{c}\text { Deteksi Dini Kanker } \\
\text { Serviks }\end{array}$ & Frekuensi & $\%$ \\
\hline Baik & 32 & 24,6 \\
Kurang Baik & 98 & 75,4 \\
Total & 130 & 100,0 \\
\hline
\end{tabular}

Tabel diatas menunjukan bahwa sebagian besar responden tidak melakukan deteksi dini kanker serviks yaitu 98 responden $(75,4 \%)$ dan terdapat 32 responden $(24,6 \%)$ yang telah melakukan deteksi.

Tabel 2 Distribusi Frekuensi Responden Berdasarkan Umur di Desa Jatimulya Wilayah Kerja Puskesmas Pedes

\begin{tabular}{ccc}
\hline Umur & Frekuensi & $\%$ \\
\hline Resiko Tinggi & 35 & 26,9 \\
Resiko Rendah & 95 & 73,1 \\
Total & 130 & 100,0 \\
\hline
\end{tabular}

Tabel diatas menunjukan bahwa 95 responden $(73,1 \%)$ berada pada umur resiko rendah dan 35 responden $(26,9 \%)$ berada pada umur resiko tinggi.

Tabel.3 Distribusi Frekuensi Responden

Berdasarkan Pendidikan di Desa Jatimulya Wilayah Kerja Puskesmas Pedes

\begin{tabular}{lcc}
\hline Pendidikan & Frekuensi & $\%$ \\
\hline Tinggi & 4 & 3,1 \\
Rendah & 126 & 96,9 \\
Total & 130 & 100,0 \\
\hline
\end{tabular}

Tabel diatas menunjukkan bahwa 126 responden $(96,9 \%)$ memiliki pendidikan 
rendah dan 4 responden $(3,1 \%)$ memiliki endidikan tinggi.

Tabel 4 Distribusi Frekuensi Responden Berdasarkan Pengetahuan di Desa Jatimulya Wilayah Kerja Puskesmas Pedes

\begin{tabular}{ccc}
\hline Pengetahuan & Frekuensi & $\%$ \\
\hline Baik & 57 & 43,8 \\
& & \\
Kurang Baik & 73 & 56,2 \\
Total & 130 & 100,0 \\
\hline
\end{tabular}

Tabel di atasbahwa $73(56,2 \%)$ menunjukan responden memiliki Pengetahuan kurang baik dan 57 responden $(43,8 \%)$ memiliki pengetahuan baik.

Tabel 5 Distribusi Frekuensi Responden Berdasarkan Sosial Ekonomi di Desa Jatimulya Wilayah Kerja Puskesmas Pedes

\begin{tabular}{ccc}
\hline Sosial Ekonomi & Frekuensi & $\%$ \\
\hline Tinggi & 32 & 24,6 \\
Rendah & 98 & 75,4 \\
Total & 130 & 100,0 \\
\hline
\end{tabular}

Tabel 5.5 di atas menunjukan bahwa 98 responden $(75,4 \%)$ memiliki sosial ekonomi rendah dan 32 responden $(24,6 \%)$ memiliki sosial ekonomi tinggi.

Tabel 6 Distribusi Frekuensi Responden Berdasarkan Jarak Ketempat Pelayanan kesehatan di Desa Jatimulya Wilayah Kerja Puskesmas Pedes Tahun 2013

\begin{tabular}{ccc}
\hline $\begin{array}{c}\text { Jarak Ketempat Pelayanan } \\
\text { Kesehatan }\end{array}$ & Frekuensi & $\%$ \\
\hline Jauh & 65 & 50,0 \\
Dekat & 65 & 50,0 \\
Total & 130 & 100,0 \\
\hline
\end{tabular}

Tabel di atas menunjukan bahwa 65 responden $(50,0 \%)$ menyatakan jauh dari jarak ketempat pelayanan, 65 responden $(50,0 \%)$ menyatakan dekat dari jarak ketempat pelayanan kesehatan.
Tabel 7 Distribusi Frekuensi Responden Berdasarkan Dukungan Keluarga di Desa Jatimulya Wilayah Kerja Puskesmas Pedes

\begin{tabular}{ccc}
\hline Dukungan Keluarga & Frekuensi & $\%$ \\
\hline Mendukung & 47 & 36,2 \\
Tidak Mendukung & 83 & 63,8 \\
Total & 130 & 100,0 \\
\hline
\end{tabular}

Tabel diatas menunjukan bahwa 83 responden $(63,8 \%)$ tidak mendapatkan dukungan keluarga sedangkan 47 responden $\quad(36,2 \%) \quad$ mendapatkan dukungan keluarga.

Tabel.8 Hubungan Umur Dengan Deteksi Dini Kanker Serviks di Desa Jatimulya Wilayah Kerja Puskesmas pedes

\begin{tabular}{|c|c|c|c|c|c|c|c|}
\hline \multirow[t]{3}{*}{ Umur } & \multicolumn{4}{|c|}{$\begin{array}{c}\text { Deteksi Dini Kanker } \\
\text { Serviks } \\
\end{array}$} & \multirow[t]{2}{*}{ Total } & & \multirow[t]{3}{*}{ P Value } \\
\hline & \multicolumn{2}{|c|}{$\mathrm{Ya}$} & \multicolumn{2}{|c|}{ Tidak } & & & \\
\hline & $\sum$ & $\%$ & $\sum$ & $\%$ & $\sum$ & $\%$ & \\
\hline Resiko Tinggi & 9 & 25,7 & 26 & 73,5 & 35 & 100,0 & 1,000 \\
\hline Resiko Rendah & 23 & 24,2 & 72 & 75,5 & 95 & 100,0 & \\
\hline Total & 32 & 24,0 & 98 & 75,4 & 130 & 100.0 & \\
\hline
\end{tabular}

Berdasarkan tabel diatas menunjukan bahwa proporsi responden yang berusia resiko tinggi melakukan deteksi dini kanker serviks sebanyak 9 responden $(25,7 \%)$ dibandingkan dengan proporsi responden yang berusia resiko rendah melakukan deteksi dini kanker serviks sebanyak 23 responden $(24,2 \%)$. Hasil uji statistik di peroleh nilai $\mathrm{p}=1,000 \quad(\mathrm{p} \leq 0,05)$ sehingga dapat disimpulkan bahwa tidak ada hubungan bermakna antara umur dengan deteksi dini kanker serviks. 
Tabel 9 Hubungan Pendidikan Dengan Deteksi Dini Kanker Serviks Di Desa Jatimulya Wilayah Kerja Puskesmas Pedes

\begin{tabular}{cccccccc}
\hline \multirow{2}{*}{ Pendidikan } & \multicolumn{4}{c}{$\begin{array}{l}\text { Deteksi Dini } \\
\text { Kanker } \\
\text { Serviks }\end{array}$} & & \\
& \multicolumn{3}{c}{ Total } & & \\
\cline { 2 - 6 } & Ya Value \\
\cline { 2 - 6 } & $\sum$ & $\%$ & $\sum$ & $\%$ & $\sum$ & $\%$ & \\
\hline Tinggi & 3 & 75,0 & 1 & 25,0 & 4 & 100,0 & 0,046 \\
Rendah & 29 & 23,0 & 97 & 76,6 & 126 & 100,0 & \\
Total & 32 & 24,6 & 98 & 75,4 & 130 & 100.0 & \\
\hline
\end{tabular}

Berdasarkan tabel diatas menunjukan

bahwa proporsi responden yang pendidikan tinggi lebih banyak melakukan deteksi dini kanker serviks sebanyak 3 responden $(75,0 \%)$ di bandingkan dengan proporsi responden yang pendidikan rendah melakukan deteksi dini kanker serviks sebanyak 29 responden $(23,0 \%)$. Hasil uji statistik di peroleh nilai $\mathrm{p}=0,046(\mathrm{p} \leq 0,05)$ sehingga dapat disimpulkan bahwa ada hubungan bermakna antara pendidikan dengan deteksi dini kanker serviks.

Tabel 10 Hubungan Pengetahuan Dengan Deteksi Dini Kanker Serviks Di Desa Jatimulya wilayah kerja Puskesmas pedes

\begin{tabular}{|c|c|c|c|c|c|c|c|}
\hline \multirow[t]{3}{*}{$\begin{array}{l}\text { Pengeta } \\
\text { huan }\end{array}$} & \multicolumn{4}{|c|}{$\begin{array}{l}\text { Deteksi Dini Kanker } \\
\text { Serviks }\end{array}$} & \multirow{2}{*}{\multicolumn{2}{|c|}{ Total }} & \multirow[t]{3}{*}{ P Value } \\
\hline & $\mathrm{Ya}$ & & & idak & & & \\
\hline & $\sum$ & $\%$ & $\sum$ & $\%$ & $\sum$ & $\%$ & \\
\hline $\begin{array}{c}\text { Baik } \\
\text { Kurang }\end{array}$ & 21 & 36,8 & 36 & 62,5 & 57 & 100,0 & 0,008 \\
\hline Baik & 11 & 15,1 & 62 & 84,7 & 73 & 100,0 & \\
\hline Total & 32 & 24,6 & 98 & 75,4 & 130 & 100.0 & \\
\hline
\end{tabular}

Berdasarkan tabel diatas menunjukan bahwa proporsi responden yang pengetahuan baik melakukan deteksi dini kanker serviks sebanyak 21 responden $(36,8 \%)$ dibandingkan dengan proporsi responden yang memiliki pengetahuan kurang baik melakukan deteksi dini kanker serviks sebanyak 11 responden $(15,1 \%)$. Hasil uji statistic di peroleh nilai $\mathrm{p}=0,008(\mathrm{p} \leq 0,05)$ sehingga dapat disimpulkan bahwa ada hubungan bermakna antara pengetahuan dengan deteksi dini kanker servik
Tabel.11 Hubungan Sosial Ekonomi Dengan Deteksi Dini

Kanker Serviks Di Desa Jatimulya Wilayah Kerja Puskesmas

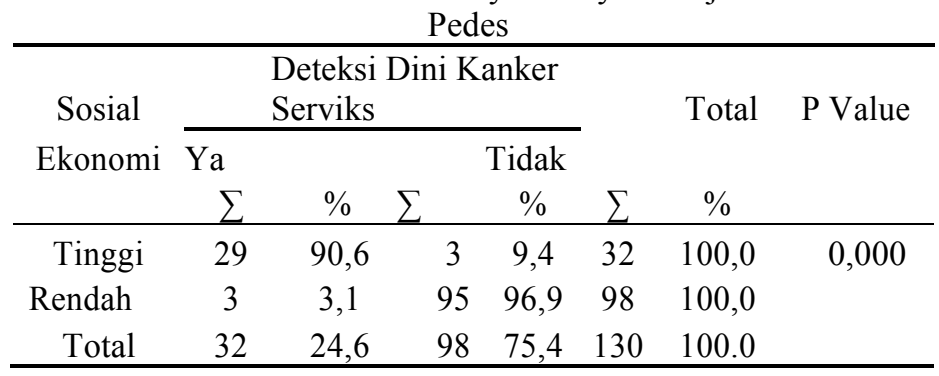

Berdasarkan tabel diatas menunjukan bahwa proporsi responden dengan sosial ekonomi tinggi melakukan deteksi dini kanker serviks sebanyak 29 responden (90,6\%) dibandingkan dengan proporsi responden yang memiliki sosial ekonomi rendah melakukan deteksi dini kanker serviks sebanyak 3 responden $(3,1 \%)$. Hasil uji statistic di peroleh nilai $\mathrm{p}=0,000 \quad(\mathrm{p} \leq 0,05) \quad$ sehingga dapat disimpulkan bahwa ada hubungan bermakna antara sosial ekonomi dengan deteksi dini kanker serviks.

Tabel 12 Hubungan Jarak Ketempat Pelayanan Kesehatan Dengan Deteksi Dini Kanker Serviks di Desa Jatimulya Wilayah Kerja Puskesmas Pedes

\begin{tabular}{|c|c|c|c|c|c|c|c|}
\hline \multirow{3}{*}{$\begin{array}{c}\text { Jarak } \\
\text { Ketempat } \\
\text { Pelayanan } \\
\text { Kesehatan }\end{array}$} & \multicolumn{4}{|c|}{$\begin{array}{l}\text { Deteksi Dini Kanker } \\
\text { Serviks }\end{array}$} & & \multirow{2}{*}{\multicolumn{2}{|c|}{ Total P Value }} \\
\hline & \multicolumn{2}{|c|}{$\mathrm{Ya}$} & \multicolumn{3}{|c|}{ Tidak } & & \\
\hline & $\sum$ & $\%$ & $\sum$ & $\%$ & $\sum$ & $\%$ & \\
\hline Dekat & 20 & 30,8 & 45 & 69,2 & 65 & 100,0 & 0,154 \\
\hline Jauh & 12 & 18,5 & 53 & 81,5 & 65 & 100,0 & \\
\hline Total & 32 & 24,6 & 98 & 75,4 & 130 & 100.0 & \\
\hline
\end{tabular}

Berdasarkan tabel diatas menunjukan bahwa proporsi responden yang menyatakan dekat dengan jarak ketempat pelayanan kesehatan dalam melakukan deteksi dini kanker serviks sebanyak 20 responden (30,8\%) dibandingkan dengan proporsi responden yang menyatakan jauh dengan jarak ketempat pelayanan kesehatan dalam melakukan deteksi dini kanker serviks sebanyak 12 responden $(18,5 \%)$. Hasil uji statistik di peroleh nilai $\mathrm{p}=0,154 \quad(\mathrm{p} \leq 0,05)$ sehingga dapat disimpulkan bahwa tidak ada hubungan bermakna antara jarak ketempat pelayanan kesehatan dengan deteksi dini kanker serviks. 
Tabel 13 Hubungan Dukungan Keluarga Dengan Deteksi Dini Kanker Serviks di Desa Jatimulya Wilayah Kerja Puskesmas Pedes

\begin{tabular}{|c|c|c|c|c|c|c|c|}
\hline \multirow{3}{*}{$\begin{array}{c}\text { Dukungan } \\
\text { Keluarga }\end{array}$} & \multicolumn{4}{|c|}{ Deteksi Dini } & \multirow[t]{2}{*}{ Total } & & \multirow[t]{3}{*}{ P Value } \\
\hline & \multicolumn{2}{|r|}{$\mathrm{Ya}$} & \multicolumn{2}{|c|}{ Tidak } & & & \\
\hline & $\sum$ & $\%$ & $\Sigma$ & $\%$ & $\Sigma$ & $\%$ & \\
\hline Mendukung & 17 & 36,2 & 30 & 63,0 & 47 & 100,0 & 0,037 \\
\hline Tidak & 15 & 18,1 & 68 & 81,7 & 83 & 100,0 & \\
\hline \multicolumn{8}{|l|}{ Mendukung } \\
\hline Total & 32 & 24,6 & 98 & 75,4 & 130 & 100.0 & \\
\hline
\end{tabular}

Berdasarkan tabel diatas menunjukan bahwa proporsi responden yang mendapatkan dukungan dalam melakukan deteksi dini kanker serviks sebanyak 17 responden $(36,2 \%)$ dibandingkan dengan proporsi responden yang tidak mendapatkan dukungan dalam melakukan deteksi dini kanker serviks sebanyak 15 responden $(18,1 \%)$. Hasil uji statistik di peroleh nilai $\mathrm{p}=0,037 \quad(\mathrm{p} \leq 0,05)$ sehingga dapat disimpulkan bahwa ada hubungan bermakna antara dukungan keluarga dengan deteksi dini kanker serviks.

\section{Gambaran Deteksi Kanker Serviks}

Penelitian menunjukan bahwa dari 130 responden, 32 responden (24,6\%) telah melakukuan deteksi dini kanker serviks sedangkan 98 responden. $(75,4 \%)$ tidak melakukan deteksi dini kanker serviks, hal ini menunjukan bahwa kesadaran wanita untuk melakukan deteksi dini kanker serviks masih rendah. Penelitian menunjukan bahwa kesadaran untuk melakukan deteksi dini kanker serviks masih rendah. Hal ini disebabkan karena berbagai alasan yang berbeda, antara lain tidak merasakan adanya gejala dari penyakit kanker serviks seperti keputihan dan perdarahan diluar siklus haid, rasa malu untuk melakukan pemeriksaan, takut menjadi tahu tentang penyakitnya dan tidak tahu pentingnya deteksi dini kanker serviks belum pernah mendapatkan informasi tentang pentingnya pemeriksaan dini kanker servik. (Tia Cristyanti, 2010)

\section{Hubungan Antara Umur dengan Deteksi Dini Kanker Serviks}

Penelitian menunjukan bahwa proporsi responden yang berusia resiko tinggi melakukan deteksi dini kanker serviks sebanyak 9 responden $(25,7 \%)$ disbandingkan dengan responden yang berusia resiko rendah melakukan deteksi dini kanker serviks 23 responden (24,2\%). Hasil uji statistik diperoleh nilai $\mathrm{p}=1,000$ $(p \leq 0,005)$ sehinga dapat disimpilkan bahwa tidak ada hubungan bermakna antara umur dengan deteksi dini kanker serviks.Teori yang mengatakan bahwa setiap wanita yang telah berhubungan seksual memiliki resiko yang sama untuk terkena kanker serviks. Namun seiring dengan peningkatan usia yang diiringi dengan penurunan kerja organ tubuh, wanita yang berusia $>35$ tahun memiliki resiko yang lebih besar untuk terkena kanker serviks (Nurcahyo, 2010). Namun hasil penelitian tidak sesuai dengan teori di atas karena deteksi dini kanker serviks dilakukan oleh wanita usia subur baik yang berusia resiko tinggi maupun yang berusia resiko rendah. Hal ini dapat disebabkan karena faktor lain selain faktor kedewasaan dan pengalaman. Salah satunya adalah faktor informasi. Seiring dengan berkembangnya teknologi, informasi di dapatkan lebih mudah. Masyarakat dapat mengakses berbagai macam sumber informasi yang menarik dari media elektronik seperti televisi, radio atau internet dan media cetak seperti majalah atau tabloid. Informasi yang didapatkan tersebut akan meningkatkan pemgetahuan wanita tentang kesehatan reproduksi dan adanya ancaman penyakit kanker serviks pada semua jenjang umur. Dengan pengetahuan yang dimilikinya, para wanita usia subur menyadari pentingnya melakukan deteksi dini 
kanker serviks dan mulai berperilaku sehat dengan memeriksakan dirinya.

\section{Hubungan Antara Pendidikan dengan Deteksi Dini Kanker Serviks}

Berdasarkan hasil penelitian dapat diketahui bahwa proporsi responden yang pendidikan tinggi lebih banyak melakukan deteksi dini kanker serviks sebanyak 3 responden $(75,0 \%)$ dibandingkan dengan proporsi responden yang pendidikan rendah melakukan deteksi dini kanker serviks sebanyak 29 responden (23,0\%). Hasil uji statistic di peroleh nilai $\mathrm{p}=0,046$ $(\mathrm{p} \leq 0,05)$ sehingga dapat disimpulkan bahwa ada hubungan bermakna antara pendidikan dengan deteksi dini kanker serviks.

Pendidikan secara umum adalah segala upaya yang direncanakan untuk mempengaruhi orang lain baik individu, kelompok atau masyarakat sehingga mereka melakukan apa yang diharapkan oleh pelaku pendidikan. (Notoatmodjo, 2005)

Pendidikan berarti bimbingan yang diberikan seseorang terhadap perkembagan orang lain menujuk kearah cita-cita tertentu yang menentukan manusia untuk berbuat dan mengisi kehidupan untuk mencapai keselamatan dan kebahagiaan. Pendidikan diperlukan untuk mendapat informasi misalnya hal-hal yang menunjang kesehatan sehingga dapat meningkatkan kualitas hidup. Pendidikan dapat mempengaruhi seseorang termasuk juga perilaku seseorang akan pola hidup terutama dalam memotivasi untuk sikap berperan serta dalam pembangunan pada umumnya, makin tinggi pendidikan seseorang makin mudah menerima informasi. (Wawan, 2010). Pendidikan akan mempengaruhi seseorang dalam pengambilan keputusan. Wanita berpendidikan tinggi dapat menerima informasi dengan lebih mudah dibandingkan dengan ibu yang berpendidikan rendah sehingga informasi tersebut dapat dilaksanakan. Tingkat pendidikan yang diperoleh seseorang dari bangku sekolah formal juga dapat mempengaruhi pengetahuan seseorang. Makin tinggi tingkat pendidikan seseorang, maka makin tinggi pula pengetahuannya tentang kesehatan. (Kasnodihardjo dalam soekanto, 2002). Intelegensi memungkinkan seseorang menjadi lebih tinggi pula sehingga penerimaan dan pemikiran seseorang terhadap suatu informasi kesehatan menjadi lebih terbuka. Selain itu dalam kehidupan sehari-hari, pendidikan kesehatan reproduksi sering kali diserentakan dalam pendidikan formal. Sehingga sedikit banyak para wanita mulai mengetahui cara menjaga kesehatan reproduksinya.

\section{Hubungan Antara Pengetahuan dengan Deteksi Dini Kanker Serviks}

Berdasarkan hasil penelitian dapat diketahui bahwa proporsi responden yang pengetahuan baik melakukan deteksi dini kanker serviks sebanyak 21 responden $(36,8 \%)$ dibandingkan dengan proporsi responden yang memiliki pengetahuan kurang baik melakukan deteksi dini kanker serviks sebanyak 11 responden $(15,1 \%)$. Hasil uji statistik di peroleh nilai $\mathrm{p}=0,008(\mathrm{p} \leq 0,05)$ sehingga dapat disimpulkan bahwa ada hubungan bermakna antara pengetahuan dengan deteksi dini kanker serviks. Hasil penelitian sesuai dengan teori diatas. Bahwa wanita yang sudah mengetahui penyebab, gejala dan cara pencegahan dari kanker serviks serta arti dan manfaat deteksi dini kanker serviks bagi dirinya akan melakukukan deteksi dini kanker serviks dan mampu memotivasi orang lain untuk melakukan deteksi dini kanker serviks. 


\section{Hubungan Antara Sosial Ekonomi dengan Deteksi Dini Kanker Serviks}

\begin{abstract}
Berdasarkan hasil penelitian dapat diketahui bahwa proporsi responden dengan sosial ekonomi tinggi melakukan deteksi dini kanker serviks sebanyak 29 responden $(90,6 \%)$ dibandingkan dengan proporsi responden yang memiliki sosial ekonomi rendah melakukan deteksi dini kanker serviks sebanyak 3 responden $(3,1 \%)$. Hasil uji statistic di peroleh nilai $p=0,000 \quad(p \leq 0,05)$ sehingga dapat disimpulkan bahwa ada hubungan bermakna antara sosial ekonomi dengan deteksi dini kanker serviks.
\end{abstract}

Sosial ekonomi mempengaruhi masyarakat untuk melakukan pemeriksaan kesehatan. Hal ini disebabkan karena untuk mendapatkan pelayanan pemeriksaan yang diperlukan masyarakat harus menyediakan dana yang diperlukan (Ahmadi, 2002). Status sosial ekonomi berpengaruh terhadap tingkah lakunya. Individu yang berasal dari kelurga yang berstatus sosial ekonominya baik dimungkinkan lebih memiliki sikap positif memandang diri dan masa depannya dibandingkan mereka yang berasal dari keluarga dengan status ekonomi rendah. (Notoatmodjo, 2003). Sosial ekonomi yang cukup memungkinkan ibu untuk peduli dan mampu mendapatkan pelayanan untuk melakukan deteksi dini kanker serviks. Sosial ekonomi keluarga dapat juga berperan penting terhadap perilaku individu. Ibu dengan keluarga yang memiliki pendapatan cukup akan lebih banyak juga mendapatkan kesempatan untuk berperilaku hidup sehat.

\section{Hubungan Antara Jarak Ketempat Pelayanan Kesehatan dengan Deteksi Dini Kanker Serviks}

Berdasarkan hasil penelitian dapat diketahui menunjukan bahwa proporsi responden yang menyatakan dekat dengan jarak ketempat pelayanan kesehatan dalam melakukan deteksi dini kanker serviks sebanyak 20 responden $(30,8 \%)$ dibandingkan dengan proporsi responden yang menyatakan jauh dengan jarak ketempat pelayanan kesehatan dalam melakukan deteksi dini kanker serviks sebanyak 12 responden $(18,5 \%)$. Menurut teori Green dalam Notoatmodjo (2010) yang meneybutkan bahwa faktor lingkungan fisik atau letak geografis berpengaruh terhadap perilaku seseorang dalam kesehatan. Salah satu penyebab kurangnya kesadaran WUS dalam mendapatkan pelayanan yang tepat adalah akibat jarak yang tidak terjangkau. jarak yang terlampau jauh dan tidak tersedianya sarana transportasi menyebabkan WUS tidak memeriksakan dirinya ketenaga kesehatan, sehingga apabila mengalami komplikasi tidak segera mendapat pertolongan yang memadai. hal ini sering menyebabkan kematian ibu (Sugiarto,2003). Jarak ketempat pelayanan yang memberikan pelayanan deteksi kanker serviks yang terjangkau bagi wanita usia subur akan meningkatan deteksi dini kanker serviks karena jarak ketempat pelayanan kesehatan membatasi kemampuan dan kemauan wanita usia subur untuk mencari pelayanan terutama jika tempat pelayanan yang tersedia terbatas, bahwa jarak dan ketersediaan pelayanan sebagai faktor pemungkin suatu motivasi terlaksananya deteksi dini kanker serviks. 


\section{Hubungan Antara Keluarga dengan Deteksi Kanker Serviks \\ ungan \\ Dini}

Berdasarkan hasil penelitian dapat diketahu bahwa proporsi responden yang mendapatkan dukungan dalam melakukan deteksi dini kanker serviks sebanyak 17 responden $(36,2 \%)$ dibandingkan dengan proporsi responden yang tidak mendapatkan dukungan dalam melakukan deteksi dini kanker serviks sebanyak 15 responden $(18,1 \%)$. Dukungan atau motivasi adalah suatu bentuk dorongan atau perhatian, serta motivasi kepada seseorang dalam upaya mencapai tujuan yang diharapkan. perilaku kesehatan seseorang atau masyarakat ditentukan oleh ada atau tidaknya dukungan dari masyarakat sekitarnya. (Green dalam Notoatmodjo, 2003)

Menurut Notoatmodjo dalam Aryati (2011), dukungan keluarga mempunyai peranan yang cukup penting dalam mempengaruhi perilaku seseorang. Di Indonesia terutama ibu-ibu, kebebasan pribadinya masih terbatas, terutama dipedesaan. Seorang istri, dalam mengambil keputusan masih sangat tergantung kepada suami dan keluarga. Mereka tidak akan melakukan sesuatu tanpa mendapatkan dukungan dari suami dan keluarga. Demikian pula, dalam mengambil keputusan mengenai deteksi dini kanker serviks harus memperoleh persetujuan dari suami atau keluarga, walaupun ibu menegtahui bahwa deteksi dini kanker serviks lebih baik, dengan adanya dorongan atau dukungan keluarga menjadi motivasi bagi ibu untuk melakukan deteksi dini kanker serviks.

\section{Simpulan}

Dari 130 responden sebanyak 32 responden $(24,6 \%)$ telah melakukuan deteksi dini kanker serviks sedangkan 98 responden $(75,4 \%)$ tidak melakukan deteksi dini kanker serviks. Berdasarkan hasil uji statistik menunjukan dari 6 variabel yang diteliti di dapatkan 4 variabel yang bermakna dan 2 variabel yang tidak bermakna. Adapun variabel yang bermakna tersebut adalah variabel pendidikan $p=0,046(p<0,05)$, variabel pengetahuan $\mathrm{p}=0,008$ $(\mathrm{p}<0,05)$, variabel sosial ekonomi $\mathrm{p}=$ $0,000 \quad(p<0,05) \quad$ dan dukungan keluarga $p=0,037(p<0,05)$.

\section{Daftar Pustaka}

http://id.wikipedia.org/wiki/Kanker) Diaskes Tanggal 7 april 2013. Jam 20:30

International Federation of Gynecology and Obstetrics (FIGO), 2000.

Laporan Puskesmas Pedes, 2013. Profil Puskesmas Pedes

Laporan Dinas Kesehatan Kabupaten Karawang 2013, Profil Dinas Kesehatan Kabupaten Karawang

Madjid, O. 2007,. Pencegahan Kanker Leher Rahim dan Kanker Payudara. Jakarta: JNPK-KR

Notoatmodjo soekidjo, 2012. Metedologi Penelitian Kesehatan. Rineka Cipta: Jakarta

Notoatmodjo, S. 2007, Promosi Kesehatan dan Ilmu Perilaku. Jakarta: Rineka Cipta

Nurcahyo, J. 2010, Awas!!! Bahaya Kanker Rahim dan Kanker Payudara. Yogyakarta: wahana totalita Publisher

Prawirohardjo, Sarwono. 2009. Ilmu Kandungan. Bina Pustaka : Jakarta

Sarwono, P. 2007. Ilmu Kandungan. Jakarta: YBPSP 
Soekanto, S. 2002. Sosiologi Suatu

Pengantar. Jakarta: PT Raja

Grafindo Persada

Wawan, A (2010). Teori dan

Pengukuran Pengetahuan, sikap dan perilaku manusia. Jakarta :

Nuha Medika

Widyastuti, Y. et.al.2009. Kesehatan

Reproduksi.

Yogyakarta:

Fitramaya. 